\title{
Załuski Wojciech, Etyczne aspekty doświadczenia czasu, Wydawnictwo Uniwersytetu Jagiellońskiego, Kraków 2017, ss. 228.
}

DOI: http://dx.doi.org/10.12775/RF.2016.033

Zagadnienie czasu to kwestia bardzo chętnie podejmowana przez myślicieli od narodzin filozofii. I nic $\mathrm{w}$ tym dziwnego - doświadczenie przemijalności (przyrody, innych ludzi, własnej) jest fenomenem tak powszechnym i tak usilnie „narzucającym się”, że nie trzeba było powstania złożonej aparatury terminologicznej i wymyślnej metodologii, by można było zacząć snuć refleksję na temat tego, co czasowe. Naturalną koleją rzeczy było więc to, że każda nowa epoka miała wielu myślicieli, którzy - pośrednio bądź bezpośrednio - do kategorii temporalności się ustosunkowywali.

Książka Wojciecha Załuskiego Etyczne aspekty doświadczenia czasu, profesora Uniwersytetu Jagiellońskiego zajmującego się głównie filozofią prawa, etyką i filozofią nauki, jest właśnie próbą syntezy owej długiej tradycji myślenia o czasie, jednak na co wskazuje tytuł monografii - syntezą ograniczoną do wyłącznie jednej perspektywy: perspektywy moralnej. Cel, jaki sobie stawia autor, to „wyróżnienie i analiza problemów etycznych wynikających z samego czasowego charakteru ludzkiego życia, to znaczy z samego faktu, iż życie ludzkie toczy się w czasie" (z okładki). Trzeba przyznać, że jest to cel ambitny, bowiem bogactwo ludzkiej praxis, której istota co do zasady wynika jedynie z faktu jej osadzenia w czasie, jest nieprzebrane.

Żeby ułatwić sobie to intelektualne wyzwanie, autor już we wstępie wymienia cechy czasu, najistotniejsze $\mathrm{z}$ punktu widzenia etyki, $\mathrm{tj}$. jego przemijalność, nieodwracalność, nieodwołalność oraz zamknięcie. To one bowiem rzutują na ewentualną ocenę moralną ludzkich czynów i pozwalają na uczestnictwo w świecie wartości. Cechy te w naturalny sposób zarysowały także problematykę, do której autor się ograniczył. Fakt, że czas przemija, a wspomnienia "zarastają", jest dla Załuskiego okazją do refleksji na temat zagadnień, które opisuje on jako „etykę pamięci", której omówieniu autor poświęca w książce najwięcej miejsca. Zagadnienia te odnoszą się przede wszystkim do przebaczenia, który 
jako szczególny akt ludzkiej woli, może łagodzić w czasie to, co w czasie nieodwołalne i nieodwracalne, co spoczywa już w jego odmętach. Dotyczą także kwestii zapominania i jego moralnych skutków, kwestii realizmu pamięci, to jest nabywania zdolności do opierania się jej tendencjom do „upiększania” wspomnień i troski o tzw. pamięć mimowolna, znaną z prozy Marcela Prousta, czyli umiejętności wskrzeszania minionych chwil, której sprzyja postawa kontemplatywna.

Poza kreśloną przez autora etyką pamięci do omawianych przez niego kwestii należą także „soteriologie czasu” (określenie autora), czyli skonceptualizowane formy jego pojmowania - niezależnie od eschatologicznych rozstrzygnięć. Ludzka egzystencja skłania bowiem człowieka nieuchronnie do opowiedzenia się za jednym ze światopoglądów uznających czas za zamknięty lub otwarty, linearny bądź kolisty. Wybór ten zdaniem autora, i nie sposób nie przyznać mu racji, jest wyborem co do zasady etycznym.

Ale czas to nie tylko przeszłość i przyszłość. Autora zajmuje nie tylko to, co minęło lub to, co nadejdzie, ale także teraźniejszość - także pojmowana w różnoraki sposób. Analizując pojęcie „,życia w teraźniejszości" autor skupia się przede wszystkim na określonych strategiach, jakie ludzie przyjmują w radzeniu sobie z tym, co przynoszą wydarzenia teraźniejsze. Okazuje się bowiem, co autor pokazuje płynnie poruszając się pomiędzy filozofią stoików, psychologią neurokognitywną i teorią ewolucji, że strategie te nie są wcale takie oczywiste. Istnieje zróżnicowany wachlarz modeli temporalnej egzystencji - nostalgiczne rozpamiętywanie przeszłości, intensywne i bezrefleksyjne „używanie” życia teraźniejszego czy obsesyjny pracoholizm jako nadzieja na lepszą przyszłość, by wymienić tylko kilka. Częściej jednak modele te łączą się w bardziej złożone kombinacje. Autor nie ogranicza się tu jedynie tylko do konstatacji, że ludzie mają tendencję do przyjmowania określonych strategii $\mathrm{w}$ przeżywaniu presji, jaki wywiera na nich przemijający czas, ani do ich opisania, lecz kreśli także swoistą pedagogikę czasu, wyrażoną w konkretnych zaleceniach i przestrogach, które wybrzmiewają w uwagach podsumowujących poszczególne podrozdziały. Podkreśla także, że każda z tych strategii pociąga za sobą określone konsekwencje.

Świadomość tego, że własne życie jest niemal mikroskopijną i efemeryczną cząstką dziejów ludzkości i same jako takie trwa bardzo krótko, musi także człowieka odpowiednio etycznie „nastrajać”. Takiemu myśleniu autor przeciwstawia szereg koncepcji, które na celu mają wyzbycie się poczucia krótkości i ulotności życia, które nazywa „miarami czasu”. W zakończeniu książki autor przyznaje się, że najbliższe są mu dwie, blisko ze sobą spokrewnione - aksjologiczna oraz gęstościowa. Kładą one nacisk nie na krótkotrwałość ludzkiego żywota, lecz na to, jak z tego czasu się korzysta. Krótkotrwałe, ale realizujące 
wysokie wartości i wywiązujące się z etycznych obowiązków życie lub "gęste" w moralnie relewantne wydarzenia, z dużym prawdopodobieństwem może uchronić człowieka przed popadnięciem w marazm lub przerażenie spowodowane uświadomieniem sobie jego kruchości. Nie dziwi więc dlaczego autor w opisie tychże miar sięga do stoików.

Najbardziej oryginalne, a zarazem najciekawsze wydają się być jednak ostatnie rozdziały książki, które dotykają tematu „pilnowania swojego czasu", budowania własnej tożsamości w czasie oraz cierpliwości jako cnoty etycznej (choć sam autor tak jej nie nazywa). W rozdziale „Pilnowanie swojego czasu" autor podnosi kwestię stosownej okazji do podjęcia określonego działania moralnie relewantnego. W etyce bardzo dużo mówi się współcześnie o czynnikach sytuacyjnych i wpływie, jaki wywierają one na podmiot moralny (wystarczy wspomnieć toczące się debatami między sytuacjonistami a zwolennikami etyki cnót). Niewiele uwagi poświęca się natomiast „swojemu czasowi”, czyli szczególnym okazjom, zwanymi przez autora chwilami kairotycznymi (od gr. Kairos - greckiego bożka szczęśliwego zbiegu okoliczności). Są to momenty wielkiej wagi, które "stwarzają możliwość wprowadzenia istotnych zmian w naszym życiu i których przeoczenie jest czymś niewłaściwym" (s. 164). Należą do nich sytuacje ważne dla członków własnej rodziny, szansa na ważne spotkanie (w rozumieniu proponowanym przez filozofię dialogu) czy szansa dojrzenia moralnego piękna drugiego człowieka. Trzeba przyznać, że snute przez Załuskiego rozważania na temat sposobnej chwili i jej roli w etyce nie powielają tego, co mówi się na ten stosunkowo rzadko podejmowany temat (odwołując się choćby do pojęcia "sytuacji granicznej” Karla Jaspersa) i noszą znamiona oryginalności.

Dwa końcowe rozdziały - „Tożsamość w czasie” oraz „Cierpliwość" - poruszają kwestie zawłaszczane w ostatnich latach przez psychologię. Rozdział przedostatni jest ważny w kontekście całości monografii, gdyż opisuje tytułowe sposoby doświadczenia czasu przez indywiduum w kontekście etycznym. $Z$ rozważań na temat głównych stanowisk w filozofii, religiach wschodnich oraz psychologii na temat tego, czy i jak istnieje tożsamość (rozumiana jako ",ja”, "podmiot", „jaźń"), wyłania się wyraźnie najbliższa autorowi koncepcji - tożsamości jako oręża do walki z czasem. Jej treść można zawrzeć w następującej maksymie: postępuj w taki sposób, aby twoje życie - przeszłe, teraźniejsze i przyszłe - było spójną całością; środkiem zaś do zbudowania jednolitej egzystencji, miałaby być służba wartościom wyższym i dbałość o stałość charakteru. Życie prowadzone w taki sposób miałoby rodzić poczucie "zwycięstwa” nad czasem, płynące ze świadomości, że tyrania przemijającego czasu nie zdołała rozbić egzystencji na nieprzystające do siebie kawałki doświadczeń i wspomnień. Koncepcja ta nie jest oczywiście nowa, autor słusznie zresztą na jej zwolenników 
znowuż wskazuje na stoików, ale także na Henryka Elzenberga, Józefa Tischnera, Jeana Guittona czy Martina Bubera. Inspirujące jest tu zatem nie tyle zreferowanie kilku stanowisk na temat tożsamości rozumianej aksjologicznie, lecz pewna świeżość ujęcia, polegające na efektywnym ich dobraniu i zestawieniu.

Z formowaniem charakteru jako twierdzy mającej przetrwać próbę czasu łączy się zagadnienie cierpliwości. Praktykowanie tej cnoty, bardzo mozolne zreszta, gdyż przeszkodą na drodze w jej praktykowaniu jest choćby ewolucyjne przystosowanie człowieka do stosunkowo szybkiego sięgania po „nagrodę”, jest niezbędnym krokiem do osiągnięcia dojrzałości charakteru. Bowiem cały wysiłek poniesiony w dbaniu o moralne życie w chwilach trudnych, "pustych", to jest pozbawionych satysfakcji z własnego wzrostu czy po prostu nużących, może spełznąć na niczym, gdy zabraknie właśnie tej cnoty. Mniejsza już o szczegóły analizy tego pojęcia i jego aksjologicznych implikacji ważniejsze jest sposób, w jaki autor ją prowadzi, a który jest konsekwentny, wyważony i wnikliwy.

Jak zostało już nieco zasygnalizowane, książka Etyczne aspekty doświadczenia czasu to nie tylko syntetyczny przegląd najważniejszych kwestii związanych z przeżywaniem czasu, rzutujących na moralność jednostek. Z tej wielopłaszczyznowej, rzetelnej, erudycyjnej oraz napisanej dobrą polszczyzną monografii wyłania się, co może jest jej największą zaleta, także pewna propozycja normatywna, przeplatająca się w każdym rozdziale z warstwą opisowa a najbardziej wybrzmiałą w zakończeniu. Szkoda tylko, że autor zdecydował się streścić wszystkie normatywne wnioski płynące $z$ tej analizy na zaledwie dwóch stronach. A przecież $\mathrm{w}$ dobie wielu dostępnych na rynku pozycji z zakresu tzw. literatury poradnikowej na temat tak modnego dziś tematu - zarządzania czasem, pewna propozycja z moralnymi wskazówkami dotyczącymi radzenia sobie ze skutkami, jakie rodzi w człowieku upływający czas, byłaby nie do przecenienia, gdyby została rozwinięta. Być może nie taki był zamysł autora, choć i tak, jego własne przemyślenia przeplatające się z myślami wielu mniej i bardziej znanych myślicieli, wskazują na złożoność tematu i stanowią solidną podstawę do własnej refleksji. Autor tejże recenzji miałby może jeszcze jedną wątpliwość, związaną z tym, że w niektórych miejscach lektury rodzi się pytanie, dlaczego jedni autorzy zostali uprzywilejowani kosztem drugich (np. postać Vladimira Jankélévitcha pojawia się prawie w każdym rozdziale). Autor ma do tego oczywiście prawo, ale można się zastanowić nad tym, dlaczego w książce nie znaleźli się inni myśliciele (np. Platon czy Tomasz z Akwinu - twórcy niemniej ciekawych koncepcji związanych z pojmowaniem czasu). Być może ten subiektywny wybór był podyktowany taką a nie inną wizją książki. 
Podsumowując - książka Wojciecha Załuskiego to ważny głos w refleksji nad relacją pomiędzy etyką a czasem. Tym bardziej, że wypełnia ona też pewną niszę, gdyż autor niniejszej recenzji nie znalazł tak obszernej pozycji na temat omawianego zagadnienia.

Dawid Winctaw 